\title{
Impaired Chemotaxigenesis by Type III Group B Streptococci in Neonatal Sera: Relationship to Diminished Concentration of Specific Anticapsular Antibody and Abnormalities of Serum Complement
}

\author{
DONALD C. ANDERSON, ${ }^{(51)}$ BONNIE J. HUGHES, MORVEN S. EDWARDS, \\ GREGORY J. BUFFONE, AND CAROL J. BAKER \\ Departments of Pediatrics, Myers-Black Section of Infectious Diseases, Microbiology and Immunology, and \\ Pathology, Baylor College of Medicine and Texas Children's Hospital, Houston, Texas, USA
}

\begin{abstract}
Summary
A chemotaxigenesis (CTG) assay employing adult or neonatal sera, type III group B streptococci (GBS) and polymorphonuclear leukocytes (PMNs) was designed to evaluate the role of PMN mobilization in the pathogenesis of type III GBS infection in neonates. Generation of $\mathrm{C} 5 \mathrm{a}$ in healthy adult sera with moderatehigh $(3-40 \mu \mathrm{g} / \mathrm{ml})$ or low $(\leq 2 \mu \mathrm{g} / \mathrm{ml})$ levels of specific anticapsular antibody was confirmed by PMN aggregometry and by the neutralization of CTG by goat anti-human C5. CTG was significantly $(P<0.001)$ greater in high as compared to low specific antibodycontaining adult sera; stepwise increases in CTG occurred when specific IgG was added to untreated, but not heat-inactivated, hypogammaglobulinemic serum. Immunospecificity of CTG was shown by a failure of type III GBS to generate C5a in heterologous (type Ia) high antibody sera. Mean CTG values in three high and 16 low antibody-containing sera from healthy term neonates were $24 \%$ and $62 \%$ of high $(P<0.001)$ and low $(P<0.01)$ antibody adult sera, respectively. The addition of both complement and specific IgG to low antibody-containing neonatal sera was required to enhance their CTG activity to high antibody adult values. CTG by type III GBS in neonatal sera-neonatal PMN mixtures was only $25 \%$ (high antibody sera) and $14 \%$ (low antibody sera) of values for paired maternal sera mixtures reacted with adult $P M N s$ $(P<0.001)$. These studies demonstrate that CTG by type III GBS in neonatal sera is markedly diminished and that low concentrations of specific anticapsular antibody and abnormalities of complement function contribute to impaired PMN mobilization in human neonates.
\end{abstract}

\section{Abbreviations}

Ab, antibody

ACP, alternative complement pathway

C4D, C4 deficiency

CH50, hemolytic complement activity

CL, chemoluminescence

CTG, chemotaxigenesis

DPBS, Dulbecco's Phosphate Buffered Saline

GBS, group B streptococci

GPS, guinea pig sera

PMN, polymorphonuclear leukocyte

THB, Todd-Hewett broth

ZAP, zymosan-activated plasma

Among inflammatory functions, the localized recruitment of phagocytic cells to foci of microbial invasion represents a critical and first line host defense mechanism $(5,32,49)$. Impaired leukocyte tissue mobilization has been demonstrated in human neo- nates and other individuals with disorders characterized by a high risk for the development of severe pyogenic infections $(5,19,37)$. Previous investigations in human neonates have demonstrated abnormalities in both the humoral and cellular contributions to leukocyte motility in vitro $(5,22,25,27,31,33,36,46)$, but specific serum requirements for generation of chemotactic factors (chemotaxigenesis) by GBS have not been determined. The experiments described in this report were designed to study the chemotactic properties of type III GBS and to define chemotaxigenic requirements in human sera for this serotype. Methods were developed to evaluate selectively the functional importance of serum antibody (IgG) specific for native III capsular polysaccharide and complement in the generation of C5a by GBS in sera from neonates and healthy adults. Markedly diminished CTG by type III GBS in neonatal sera was demonstrated and was related both to low concentrations of specific antibody and abnormalities of complement function.

\section{MATERIALS AND METHODS}

Isolation of PMN. Venous blood samples were collected from a single adult volunteer and the placentas of healthy neonates in a syringe containing 10 units of sodium heparin per $\mathrm{ml}$ of blood. After sedimentation of erythrocytes in dextran, leukocyte-rich plasma was layered over a Ficoll-Hypaque solution consisting of 10 parts of 33.9\% Hypaque (Winthrop Labs, New York, NY) and 24 parts of 9\% Ficoll (Sigma Chemical Co., St. Louis, MO) and centrifuged at $800 \times g$ for $30 \mathrm{~min}$. For use in $\mathrm{CL}$ and aggregometry studies, remaining erythrocytes were lysed in distilled water, and isotonicity was restored with $1.8 \% \mathrm{NaCl}$. Purified suspensions of PMNs were washed thoroughly and resuspended in DPBS, $\mathrm{pH}$ 7.3, which contained $0.2 \%$ dextrose (Grand Island Biological Co., Grand Island, NY). The final cell concentration was adjusted to a $1 \times 10^{7} \mathrm{PMN} / \mathrm{ml}$ by addition of DPBS.

Preparation of organisms. The strains of GBS used in these investigations were type III (M732, M781, and M803) and type Ia (R515) clinical isolates from infants with noenatal meningitis and Lancefield prototype Ia strain 090 . Frozen aliquots $\left(-20^{\circ} \mathrm{C}\right)$ of bacteria were inoculated into $10 \mathrm{ml}$ of THB and incubated at $37^{\circ} \mathrm{C}$ overnight. The suspensions were adjusted to an appropriate optical density for each strain (0.85-0.95 at $540 \mathrm{~nm}$ ) (Spectronic 20, Bausch \& Lomb, Rochester, NY). These suspensions were centrifuged at $1000 \times g$ for $10 \mathrm{~min}$ at $25^{\circ} \mathrm{C}$, washed, and resuspended in an equal volume of DPBS. These preparations consistently contained $5 \times 10^{8}-10^{9}$ colony forming unit $/ \mathrm{ml}$.

Sera. Samples of whole blood were obtained from 13 healthy adult volunteers, the placentas of 21 healthy full-term (gestational age, $37-40 \mathrm{wk}$ ) infants, and from the mothers of five of these infants at the time of delivery. Informed consent to perform 
phlebotomy was obtained from the mothers of study infants and adult control donors. Placental samples were processed immediately. Samples were allowed to clot at room temperature (about $25^{\circ} \mathrm{C}$ for $30 \mathrm{~min}$ ) and sera were separated by centrifugation and frozen in aliquots at $-70^{\circ} \mathrm{C}$ before testing. Aliquots of these sera were heated at $56^{\circ} \mathrm{C}$ for $30 \mathrm{~min}$ to inactivate complement or were chelated at $25^{\circ} \mathrm{C}$ for $10 \mathrm{~min}$ with $4 \mathrm{mM} \mathrm{MgCl}$ and $8 \mathrm{mM}$ EGTA (Sigma Chemical Co.) (15). Sera from GPS with homozygous C4D and normal guinea pigs were processed in a similar manner following phlebotomy.

Sera were selected for use in these investigations on the basis of their concentrations of specific antibody to capsular antigens of type III GBS (4). Adult and neonatal samples were categorized into groups containing moderate-high $(3-42 \mu \mathrm{g} / \mathrm{ml})$ or low $(<2$ $\mu \mathrm{g} / \mathrm{ml}$ ) levels of specific antibody. In functional assays, comparisons between test sera containing $>2 \mu \mathrm{g} \mathrm{Ab} / \mathrm{ml}$ in contrast to $<2$ $\mu \mathrm{g} \mathrm{Ab} / \mathrm{ml}$ were based on previous studies demonstrating susceptibility to type III GBS disease only among infants whose serum contains $<2 \mu \mathrm{g} \mathrm{Ab} / \mathrm{ml}$ (7). Serum from an adult with common variable immune deficiency disease [IgG, $143 \mathrm{mg} / \mathrm{dl}$; IgA, $9 \mathrm{mg} /$ $\mathrm{dl}$; IgM, $21 \mathrm{mg} / \mathrm{dl}$; and specific antibody, $<0.3 \mu \mathrm{g} / \mathrm{ml}$ (type III, $<1.8 \mu \mathrm{g} / \mathrm{ml}$ (type Ia)] was employed in reconstitution experiments requiring exogenous complement.

Serum complement determinations. Quantitation of CH50 in test sera was determined as previously described (30), and concentrations of complement components $\mathrm{C} 3, \mathrm{C} 4$, and Factor B were determined with an immunonephelometric technique (Atlantic Antibody, Scarborough, MN) (11). Concentration of C5 was determined by radial immunodiffusion with $\mathrm{C} 5$ antisera (Miles Labs, Elkhart, IN) (29). Partially purified C5 was prepared by the method of Hammer et al. (20) with only minor modifications. The material was not passed over an immunoadsorbent for $\mathrm{IgG}$ and IgA, the only contaminants demonstrated by SDS-PAGE. The concentration of $\mathrm{C} 5$ determined by electroimmunoassay was 27 $\mu \mathrm{g} / \mathrm{ml}$. Hemolytic activity was determined using cellular intermediates and complement component from Cordis Laboratories (Miami, FL). The hemolytic activity was 569 units $/ \mu \mathrm{g} / \mathrm{ml}$ as compared to a normal serum with an activity of $994 \mathrm{unit} / \mu \mathrm{g} / \mathrm{ml}$.

IgG preparation. Purified IgG was prepared from adult donor serum known to contain a high concentration $(20 \mu \mathrm{g} / \mathrm{ml})$ of specific antibody to native type III GBS polysaccharide. Serum was treated with octanoic acid followed by DEAE chromatography (43). Contaminating $\operatorname{IgG}$ or $\operatorname{IgA}$ were removed by passage over the appropriate antibody coated sepharose 4B column.

Radioactive antigen-binding assay. The concentration of antibody to native type Ia or III GBS polysaccharides in adult or neonatal human sera and in GPS was determined by a radioactive antigen-binding assay described previously $(8,9)$. Antigens used in the present studies were purified native type III and type III capsular polysaccharides intrinsically labeled with $\left[{ }^{3} \mathrm{H}\right]$. Antigens were provided by Dr. Dennis Kasper, Channing Laboratory, Harvard Medical School, Boston, MA.

Luminol-enhanced phagocytosis-CL assay. Opsonic mixtures containing bacterial suspensions $\left(0.5 \mathrm{ml} ; 5 \times 10^{8}\right.$ colony forming units in DPBS $)$, serum $(0.25 \mathrm{ml})$, and DPBS $(0.25 \mathrm{ml})$ were reacted for $45 \mathrm{~min}$ at $37^{\circ} \mathrm{C}$ in a shaking water bath. Bacteria were then centrifuged at $4^{\circ} \mathrm{C}$, washed twice and resuspended in DPBS. Final phagocytic reaction mixtures contained $2.5 \times 10^{6} \mathrm{PMNs}, 4 \times 10^{8}$ colony forming units of opsonized or unopsonized bacteria, and $10^{-7}$ M luminol (5-amino-2,3-dihydroxy-1,4-phthalazine dione) (Sigma Chemical Co.). Quantitation of $\mathrm{CL}$ was performed on duplicate samples in a liquid scintillation counter (model \#C-2425 Tri-Carb, Packard Instruments, Houston, TX) with the coincidence circuit disengaged. CL data was presented as the integral (area under the curve) of the CL response between $0-75 \mathrm{~min}$ after initiation of phagocytosis (4).

CTG assays. Opsonic mixtures containing type III or type IA Group B S and test sera as prepared for $C L$ experiments were incubated at $37^{\circ} \mathrm{C}$ for $45 \mathrm{~min}$ before $\mathrm{CG}$ determinations. Opsonized organisms were removed from test sera by centrifugation at $10,000 \times g\left(4^{\circ} \mathrm{C}\right)$ for $15 \mathrm{~min}$. The supernatant of each opsonic mixture was transferred to sterile vials and heated for $30 \mathrm{~min}$ at $56^{\circ} \mathrm{C}$ to avoid nonspecific complement activation (23). Aliquots were then diluted to a final concentration of $12 \frac{1}{2} \%(\mathrm{v} / \mathrm{v})$ in DPBS for use in chemotaxis assays. Control opsonic mixtures containing type Ia or type III GBS without serum and serum alone were included in each experiment.

Directed migration of healthy adult or neonatal PMN leukocytes was assessed by a modified Boyden technique (5). Supernatants of opsonic reaction mixtures were placed in the stimulant compartments of blindwell chemotaxis chambers together with 3$\mu \mathrm{m}$ micropore filters (Millipore Corp., Bedford, MA). PMNs (0.2 $\mathrm{ml}, 2 \times 10^{6} \mathrm{PMN} / \mathrm{ml}$ ) were then added to the cell compartment of chambers, which were incubated at $37^{\circ} \mathrm{C}$ in a $\mathrm{CO}_{2}$ environment for varying time intervals. The behavior of PMN migration in this system was evaluated by determining the depths into filters at which only two cells were in focus in one high power field ("leading front") after 80 min incubation (14). Directed migration values were determined by subtracting random motility values (phosphate buffered saline alone in the stimulant compartment) from total migration "leading front" values.

Characterization of serum-derived chemotactic factor(s). To determine the nature of the chemotactic factor(s) produced in serum by type III GBS, test mixtures were employed in PMN aggregometry and adherence assays. PMN aggregometry was performed as previously described $(14,21,35)$ using test serum incubated with zymosan, bacteria, or DPBS to effect aggregation of cytochalasin B pretreated $\left(50 \mu \mathrm{g} / \mathrm{ml}, 37^{\circ} \mathrm{C}, 15 \mathrm{~min}\right)$ PMNs obtained from a single healthy adult. In preliminary experiments, an arbitrary scale was established in which ZAP yielded $100 \mathrm{ZAP}$ deflection units; a 1:2 dilution of ZAP in DPBS yielded 50 ZAP units, etc. The aggregating activities of GBS-serum reactants were measured at 4-min intervals and were expressed in ZAP units (39). In parallel experiments, selected GBS-serum reactants were also assessed for enhancement of PMN adherence for protein-coated substrates as previously described (40).

Anti-human C5 (goat) antiserum (Behring Diagnostics, Sommerville, NJ) was heated $\left(56^{\circ} \mathrm{C}, 30 \mathrm{~min}\right)$ and centrifuged at 10,000 $\times g$ for $10 \mathrm{~min}$. A $100 \mu \mathrm{l}$ of antiserum was then incubated for 30 min at $37^{\circ} \mathrm{C}$ with $0.5 \mathrm{ml}$ of the supernatant of selected opsonic mixtures. The resulting preparations were then assayed for PMN chemotactic, aggregating, and adherence promoting activities (39, 40).

\section{RESULTS}

Chemotactic and chemotaxigenic activity generated by Type III or Ia GBS. To determine the relative contributions of chemotaxigenic activity derived from bacteria-serum interactions compared with that due to bacteria alone, dose response experiments were performed (Fig. 1). Chemotactic activity was observed in the supernatants of both type III and Ia GBS suspensions incubated in the absence of serum; however, this activity was not detectable when these reactants were diluted to a $10 \%(\mathrm{v} / \mathrm{v})$ concentration in DPBS. Chemotactic activity generated by both GBS serotypes in the presence of $25 \%(\mathrm{v} / \mathrm{v})$ serum was significantly greater than that generated without serum. Anti-C5 pre-incubation neutralized activity generated in GBS-serum mixtures but not that of GBS organisms without serum. As shown, maximal activity in this experimental system was demonstrated when $15 \%(\mathrm{v} / \mathrm{v})$ concentrations of opsonic supernatants were employed; lower values occurred at higher or lower concentrations. A $12.5 \%(\mathrm{v} / \mathrm{v})$ final concentration was selected for all subsequent experiments to exclude the influence of serum independent (bacterial) chemotactic factors and thus, to allow selective evaluations of CTG by GBS in test sera.

\section{CTG in Serum by Type III GBS: Role of Specific Antibody and Complement}

Kinetics of CTG. The kinetics of chemotaxigenic activity generated by type III GBS in untreated, chelated, or heated serum is illustrated in Figure 2. Test sera included normal adult serum containing a high level of type III-specific anticapsular antibody 


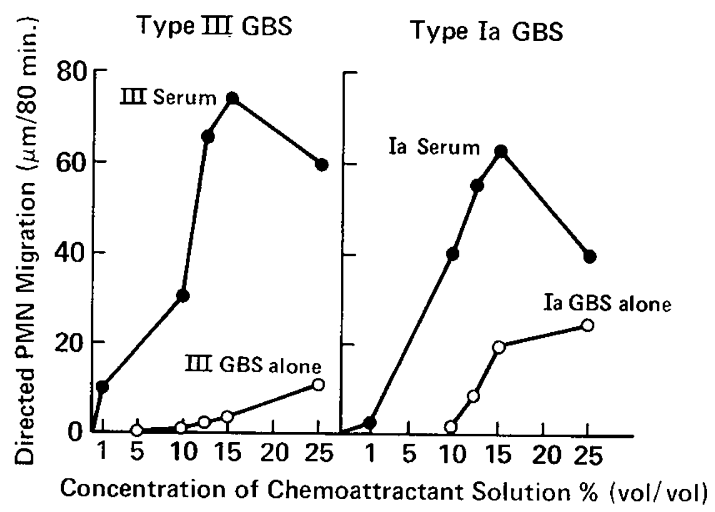

Fig. 1. Chemotaxigenesis by type III (M732) or type Ia ( 515 group B streptococcus (GBS) (-) in healthy adult serum containing high concentrations of type III or Ia specific antibody and cytotactic activities of supernatants of GBS suspensions without serum $(\mathrm{O}-\mathrm{O})$. Serial dilutions of the supernatants of GBS-serum/PBS mixtures were incorporated in the stimulant compartment of Boyden Chambers. Values shown represent the mean of three experiments.

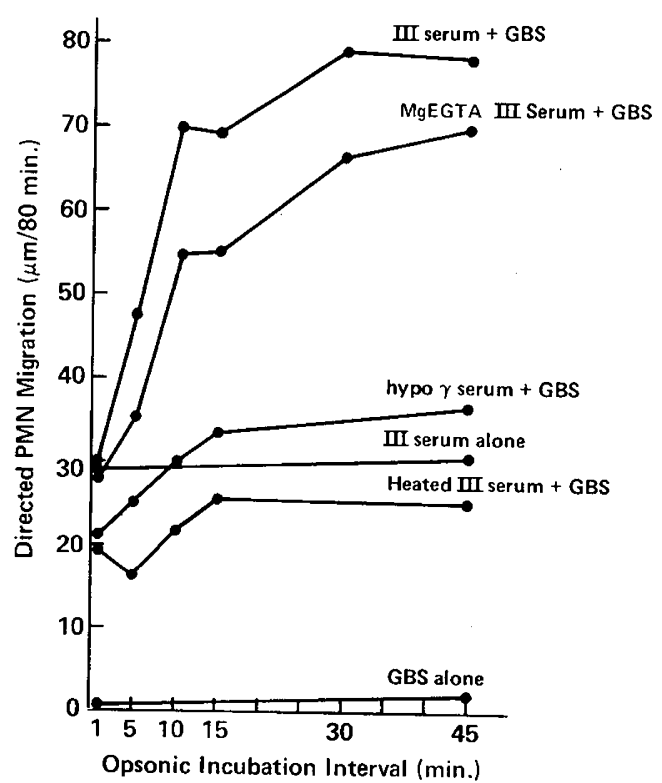

Fig. 2. The kinetics of chemotaxigenesis by type III GBS in (1) adult serum containing high concentrations of specific antibody (III serum), (2) the same serum following MgEGTA-chelation (MgEGTA) or heat-inactivation (1) and (3) hypogammaglobulinemic serum (hypo $\gamma$ ). These data represent the mean of three separate experiments performed in triplicate. Values for III serum at $5,10,15$, and 30 min time intervals are significantly $(P<0.05)$ increased compared to MgEGTA-chelated serum.

$(29.1 \mu \mathrm{g} / \mathrm{ml})$ and hypogammaglobulinemic serum $(<0.3 \mu \mathrm{g} / \mathrm{ml})$. These studies were performed by incubating $5 \times 10^{8}$ organisms in $25 \%$ (v/v) test sera for $1,5,10,15,30$, or 45 min. Maximal activity generated in untreated high antibody-containing sera was observed after $10-15 \mathrm{~min}$ incubation intervals. In contrast, the rate of CTG in MgEGTA-treated sera was delayed, but maximal values achieved were $=88 \%$ of those in untreated sera. After 45 min incubation intervals, only minimal increments were observed in hypogammaglobulinemic serum, and determinations in heated serum or serum incubated without GBS were essentially comparable to respective 1 -min interval samples.

CTG by type III GBS in untreated, MgEGTA-chelated and heated adult sera. The chemotaxigenic contributions of specific antibody and/or complement are summarzied in Figure 3. Data shown represent experiments performed with strain M732 although similar results were observed when these sera were tested

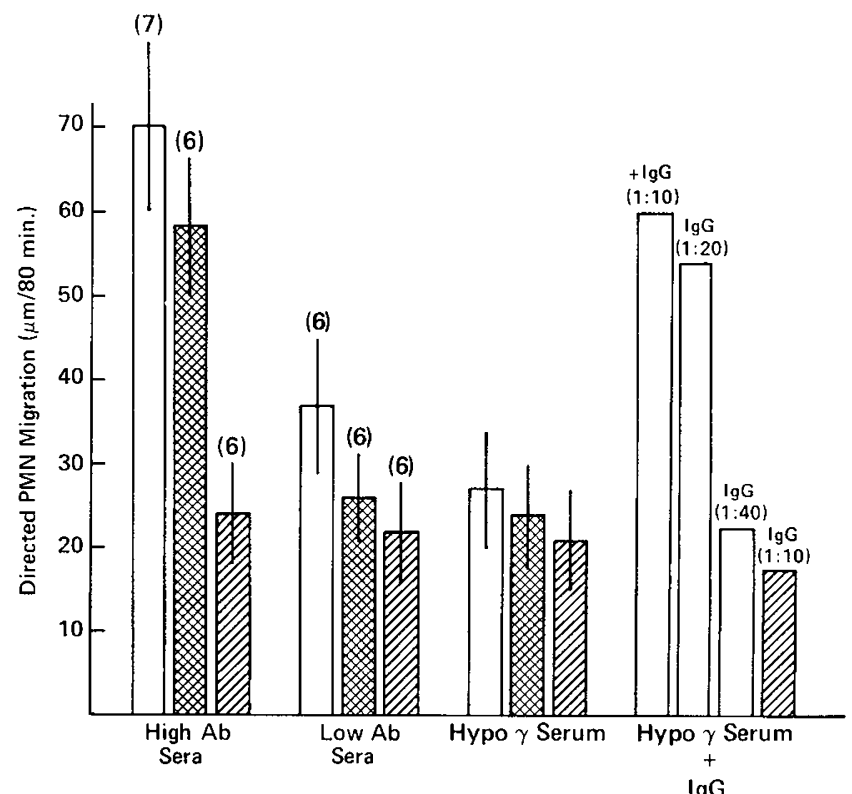

Fig. 3. Chemotaxigenesis by type III GBS in untreated (匚), MgEGTA-chelated ( $(>)$ ) or heated $(/ / / / / /)$ sera containing moderateto-high $(4.8-41.8 \mu \mathrm{g} / \mathrm{ml})$, low $(\leq 2 \mu \mathrm{g} / \mathrm{ml})$ or undetectable concentrations (hypo $\gamma$ ) of type III specific antibody. Directed migration values shown represent the mean \pm S.D. of mean values determined for a minimum of three experiments performed on each serum obtained from $(n)$ healthy adult donors. Purified $\mathrm{IgG}$ at varous dilutions was added to untreated and heated hypogammaglobulinemic serum.

with type III GBS strains M781 and M803 (data not shown). Mean directed migration \pm S.D. values for untreated moderateto-high antibody containing sera $(70 \pm 9 \mu \mathrm{m})$ were significantly greater than those of six low antibody sera $(37 \pm 8 \mu \mathrm{m})$ or hypogammaglobulinemic serum $(27 \pm 8 \mu \mathrm{m})(P<0.001$ for both). Determinations in high or low antibody sera (but not hypogammaglobulinemic serum) were significantly increased compared to respective heat-treated samples $(P<0.01$ by paired " $t$ " test $)$. Among each serum group, mean values for heated sera were comparable to those of sera incubated in the absence of GBS. In addition, for representative test sera containing high, low, or undetectable antibody concentrations, anti-C5 preincubation diminished CTG values to approximately those noted in heat-inactived sera.

Values (mean \pm 1 S.D.) for MgEGTA-chelated moderate-tohigh antibody sera $(58 \pm 8 \mu \mathrm{m})$ were diminished compared to respective untreated sera values, but differences observed were not statistically significant $(P<0.05)$. These values were significantly $(P<0.01)$ increased when compared to respective heated sera $(24$ \pm 6 ). In contrast, chemotaxigenic activities in chelated low antibody and hypogammaglobulinemic sera were comparable to those of respective heated sera $(P<0.05)$. Similar relationships were observed with C4D or normal GPS reconstituted with IgG.

The importance of specific antibody in promoting CTG by type III GBS was further emphasized by reconstitution experiments employing purified IgG (35 $\mu \mathrm{g} \mathrm{Ab} / \mathrm{ml})$. Enhancement of chemotaxigenic activity in hypogammaglobulinemic serum to values approximately equal to those of high antibody adult sera was achieved with a $1: 10$ or a 1:20 dilution of this IgG preparation. In contrast, when IgG was added to heated hypogammaglobulinemic serum, no increments in activity were observed.

Immunospecificity of CTG by type III GBS. The specificity of antibody-augmented CTG with respect to types III (M732) or Ia (515) GBS is shown in Table 1. Representative sera containing high or low specific antibody concentrations to type III or la capsular polysaccharides were incubated with heterologous or homologous organisms. Significantly greater CTG was derived by incubating type III organisms in high anti-III, low anti-Ia sera as 
compared to high anti-Ia, low anti-III sera $(P<0.01)$, or compared to hypogammaglobulinemic serum $(P<0.01)$. Similarly, significantly greater CTG was observed when type Ia GBS were incubated in high anti-Ia + low anti-III sera as compared to that generated in high anti-III + low anti-Ia or low anti-III + low antiIa sera $(P<0.01)$.

$C T G$ by type III GBS in neonatal sera. The contributions of specific antibody and complement to CTG by type III GBS were evaluated in cord sera from 19 neonates. Activity was compared to that of paired maternal samples and adult sera containing various concentrations of specific antibody. As shown in Table 2, normal total $\mathrm{CH} 50$ and normal concentrations of $\mathrm{C} 3, \mathrm{C} 4, \mathrm{C} 5$, and Factor $\mathrm{B}$ were demonstrated in all maternal and adult test sera. Among neonatal sera samples tested, mean $\mathrm{CH} 50$ values and mean concentrations of $\mathrm{C} 3, \mathrm{C} 4$, and Factor B were significantly diminished compared to healthy adult sera as has been previously reported $(1,38)$. No differences in mean $\mathrm{CH} 50$ values or $\mathrm{C}^{\prime}$ component concentration were observed among adult or neonatal sera containing high as compared to low concentrations of specific antibody to type III GBS.

Total and heat stable chemotaxigenic act lvities of neonatal sera containing moderate-high $(8.9-38.3 \mu \mathrm{g} / \mathrm{ml})$ or low $(0.1-1.8 \mu \mathrm{g}$ $\mathrm{Ab} / \mathrm{ml}$ ) concentrations of specific antibody are shown in Figure 4 and are compared to those of respective adult sera groups. Mean total values for high or low antibody-containing neonatal sera groups were significantly $(P<0.001)$ diminished when compared to those of high antibody-containing adult sera. Mean total values in high antibody neonatal sera were comparable to those of low antibody adult sera $(P<0.05)$, but those for low antibody neonatal sera were significantly $(P<0.01)$ diminished compared to those of both adult serum groups; moreover, when differences between total and heat-stable activity were computed for each test serum, mean increments generated in low antibody neonatal sera $(7 \pm 6$ $\mu \mathrm{m})$ were significantly less than in high antibody $(46 \pm 9 \mu \mathrm{m})(P$ $<0.001)$ or low antibody $(15 \pm 4 \mu \mathrm{m})(P<0.05)$ adult sera, and significantly $(P<0.05)$ less than those in high antibody neonatal sera $(17 \pm 8 \mu \mathrm{m})$.

Considerable heterogeneity among low antibody neonatal test sera was observed. Total activity as assessed in this experimental

Table 1. Immunospecificity of chemotaxigenesis by type III or Ia group B Streptococcus

\begin{tabular}{|c|c|c|c|c|}
\hline \multirow[b]{2}{*}{$\begin{array}{c}\text { Test } \\
\text { serum }\end{array}$} & \multicolumn{2}{|c|}{$\begin{array}{l}\text { Specific antibody } \\
\text { concentration } \\
\text { in test serum } \\
(\mu \mathrm{g} / \mathrm{ml})\end{array}$} & \multicolumn{2}{|c|}{$\begin{array}{l}\text { Chemotaxigenic } \\
\text { activity } \\
(\mu \mathrm{m} / 80 \mathrm{~min})\end{array}$} \\
\hline & Anti-III & Anti-Ia & $\begin{array}{l}\text { Type III GBS } \\
\text { (M732) }\end{array}$ & $\begin{array}{c}\text { Type Ia GBS } \\
(515)\end{array}$ \\
\hline$\# 1$ & 29.1 & $<1$ & $65^{1}$ & 42 \\
\hline$\# 2$ & $<0.3$ & 6.4 & 37 & 69 \\
\hline$\# 3$ & $<0.3$ & $<1.8$ & 34 & 37 \\
\hline$\not 4^{2}$ & 35 & $<1$ & 70 & 42 \\
\hline
\end{tabular}

${ }^{1}$ Represents mean values of three experiments performed with each test serum.

${ }^{2}$ Test serum \#3 reconstituted with specific IgG. system ranged from $10-34 \mu \mathrm{m}$ for the 16 low antibody neonatal sera tested. Individual values among this group were not directly related to serum concentrations of specific antibody; thus, variable activity observed among low antibody neonates may be related to differences in serum complement function. The lowest individual values (both total activity and increment) were observed in a neonatal sample containing the lowest $\mathrm{CH} 50$ titer among all sera tested.

As shown in Table 3, representative low antibody containing neonatal sera were reconstituted with purified IgG and/or complement (hypogammaglobulinemic adult sera). In those experiments, hypogammaglobulinemic serum $(0.25 \mathrm{ml})$ was incorporated into opsonic mixtures containing test sera $(0.25 \mathrm{ml})$ and $5 \times 10^{8}$ organisms $(0.5 \mathrm{ml})$. When exogenous complement in addition to purified IgG (but not either individually) were added to reaction mixtures, the chemotaxigenic activities of neonatal sera were comparable to that of high antibody adult sera.

Additional influence of neonatal PMN motility on chemotaxigenesis by type III GBS. To further study the capacity of type III GBS to effect leukocyte mobilization in neonates, the influence of antibody and/or complement in neonatal sera was assessed with respect to adult and neonatal PMNs (Fig. 5). Mean chemotaxigenic activity for healthy adult PMNs (expressed as mean \% of high antibody adult sera values) in high antibody maternal sera (102\%) was significantly greater than that generated in low antibody maternal sera $(55 \%)$, high antibody neonatal sera $(48 \%)$, or low antibody neonatal sera $(28 \%)(P<0.001)$. Further, mean low

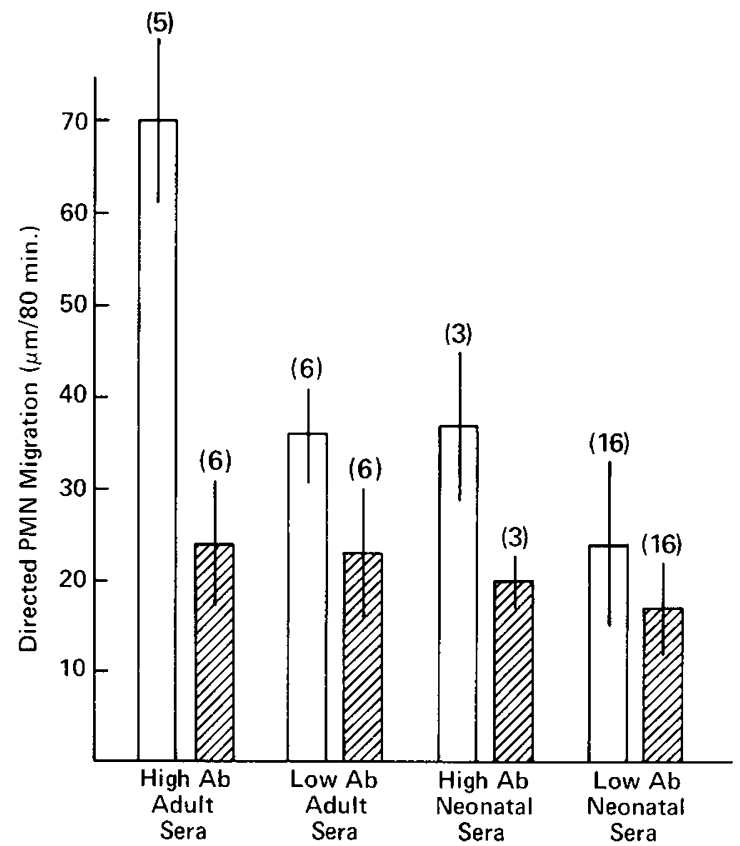

Fig. 4. Chemotaxigenesis by type III GBS in untreated ( $\square$ ) or heat-inactivated $(1 / / / / /)$ adult or neonatal sera containing high or low concentrations of specific antibody. Directed migration values represent the mean \pm 1 S.D. of mean values from a minimum of three experiments performed on each serum from $(n)$ donors.

Table 2. Serum complement determinations in neonatal and adult test sera

\begin{tabular}{lccccc}
\hline \multicolumn{1}{c}{ Serum source } & CH50 (unit/ml) & C3 (mg/dl) & C4 (mg/d) & C5 (mg/dl) & Factor B (mg/dl) \\
\hline Adult sera (13) & $317 \pm 26^{1}$ & $108 \pm 14$ & $23 \pm 6$ & $13.5 \pm 4$ & $33 \pm 6$ \\
Maternal sera (5) & $316 \pm 46$ & $115 \pm 14$ & $26 \pm 14$ & $16 \pm 4$ & $39.5 \pm 6$ \\
$\begin{array}{l}\text { Hypogammaglobu- } \\
\text { linemic serum (1) }\end{array}$ & 309 & 118 & 22 & 32 \\
Neonatal sera (22) & $263 \pm 61^{2}$ & $85 \pm 8^{2}$ & $12.4 \pm 4^{3}$ & $12 \pm 1.5$ & $15 \pm 3.5^{3}$ \\
\hline
\end{tabular}

${ }^{1}$ Represents the mean \pm 1 S.D. of $n$ individual values.

${ }^{2}$ Significantly less than adult sera values $(P<0.01)$.

${ }^{3}$ Significantly less than adult sera values $(P<0.001)$. 
Table 3. Comparison of chemotaxigenic and opsonic activity for type III group B streptococcus in neonatal sera

\begin{tabular}{|c|c|c|c|c|c|c|c|c|}
\hline \multirow[b]{2}{*}{ Serum source } & \multirow[b]{2}{*}{$n$} & \multirow[b]{2}{*}{$\begin{array}{c}\text { RABA } \\
(\mu \mathrm{g} \mathrm{Ab} / \mathrm{ml})\end{array}$} & \multicolumn{2}{|c|}{ Chemotaxigenesis } & \multicolumn{2}{|c|}{ Aggregometry } & \multicolumn{2}{|c|}{ Opsonic-chemiluminescence } \\
\hline & & & $\begin{array}{c}\overline{\mathrm{x}} \pm 1 \text { S.D. } \\
(\mu \mathrm{m} / 80 \mathrm{~min})\end{array}$ & $\begin{array}{l}\overline{\mathbf{x}} \% \text { High } \\
\text { antibody } \\
\text { adult sera }\end{array}$ & $\overline{\mathrm{x}}$ ZAP Units & $\begin{array}{l}\bar{x} \% \text { High } \\
\text { antibody } \\
\text { adult sera }\end{array}$ & $\overline{\mathrm{x}} \mathrm{AUC} \times 10^{6}$ & $\begin{array}{l}\overline{\mathrm{x}} \% \text { High } \\
\text { antibody } \\
\text { adult sera }\end{array}$ \\
\hline High antibody neonate & 2 & $8.9-38.3$ & $34 \pm 10$ & 49 & ND & & 105 & 56 \\
\hline Low antibody neonate & 6 & $0.3-1.8$ & $24 \pm 6$ & 36 & 6 & 33 & 86 & 45 \\
\hline $\begin{array}{l}\text { Low antibody neonate }+ \\
\qquad \mathrm{IgG}^{1}\end{array}$ & 4 & $35^{1}$ & $54 \pm 8^{2}$ & 81 & 13 & 70 & 111 & 59 \\
\hline $\begin{array}{l}\text { Low antibody neonate }+ \\
C^{\prime 3}\end{array}$ & 4 & $0.3-1.8$ & $37 \pm 8^{4}$ & 55 & 13 & 70 & $116^{4}$ & 61 \\
\hline $\begin{array}{l}\text { Low antibody neonate }+ \\
C^{\prime 3}+\operatorname{IgG}^{1}\end{array}$ & 4 & $35^{1}$ & $71 \pm 8^{2}$ & 102 & 23 & 127 & $163^{2}$ & 86 \\
\hline
\end{tabular}

${ }^{1}$ Reconstituted with purified specific IgG (35 $\mu \mathrm{g}$ antibody/ml).

${ }^{2} P<0.001$ compared to low antibody neonatal sera.

${ }^{3} \mathrm{C}^{\prime}$, untreated serum from hypogammaglobulinemic patient $(<0.3 \mu \mathrm{g}$ antibody $/ \mathrm{ml})$.

${ }^{4} P<0.01$ compared to low antibody neonatal sera.

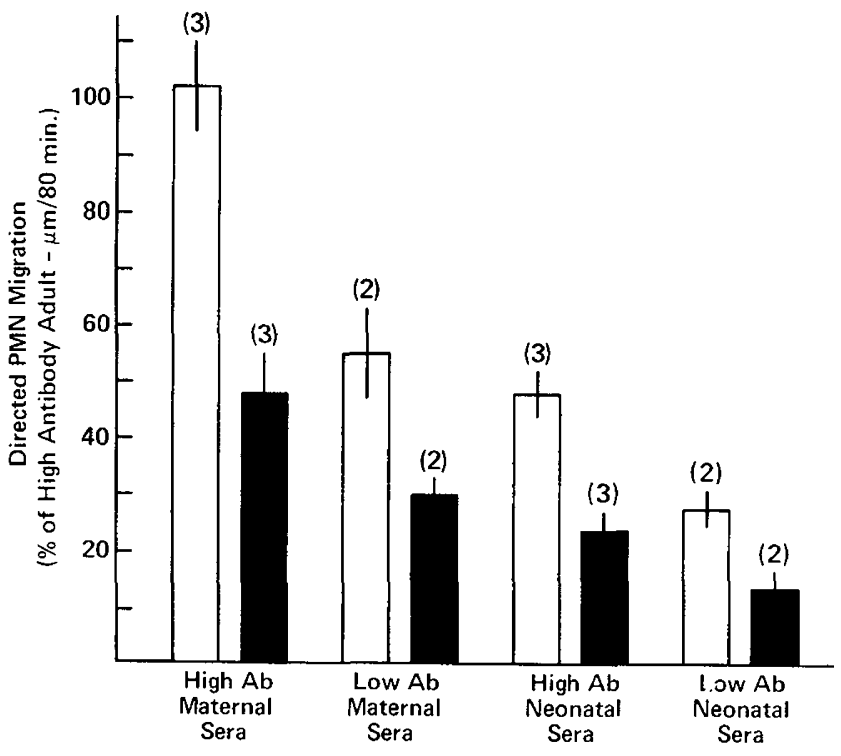

Fig. 5. Chemotaxigenesis by type III GBS in paired maternal-neonatal sera containing moderate-to-high $(4.8-41.8 \mu \mathrm{g} / \mathrm{ml})$ or low $(\leq 2 \mu \mathrm{g} / \mathrm{ml})$ concentrations of specific antibody. GBS-serum supernatants were employed together with healthy adult PMNs ( $(\square$. Values shown represent the mean \pm I S.D. values of experiments performed on $(n)$ sera.

antibody neonatal sera values were significantly $(P<0.001)$ diminished compared to all other test sera groups. More striking differences were evident when the same opsonic mixtures were utilized to stimulate locomotion of neonatal PMNs. Directed migration values for neonatal PMNs ranged from $25-40 \%$ of adult PMN migration scores in response to the same opsonic supernatant. Values for high or low antibody neonatal sera reacted with neonatal PMNs were $24 \%$ and $14 \%$ of values for high antibody maternal sera reacted with adult PMNs, respectively $(P<0.001)$. Values for all low antibody neonatal serum + neonatal PMN mixtures were diminished compared to all reaction mixtures employing maternal sera and/or adult PMNs.

Characterization of type III GBS chemotaxigens. To confirm that C5a generation accounts for the majority of chemotactic activity derived from GBS serum interactions, investigations of the PMN aggregating and/or adherence promoting activities of opsonic supernatants were performed $(1,40)$. As in chemotaxigenesis experiments, high antibody adult sera $(n=5)$ values $(\overline{\mathrm{x}}=18$ ZAP units), hypogammaglobulinemic sera ( $\overline{\mathrm{x}}=7$ ZAP units), or low antibody neonatal sera ( $\overline{\mathrm{x}}=6 \mathrm{ZAP}$ units). Approximately
$85 \%$ of aggregating activity in all test sera was neutralized by antiC5 pre-incubation, and no aggregating activity was demonstrable in reaction mixtures employing heat-inactivated sera or GBS organisms alone. In control experiments, no neutralization of activity by anti-albumin was observed. Reconstitution of hypogammaglobulinemic adult serum with purified $\mathrm{IgG}$ increased its aggregating activity from 6-21 ZAP units, but no enhancement of activity was apparent when IgG was added to the same serum after heat inactivation. As shown in Table 3, mean activity observed in six representative low antibody neonatal sera reactants increased from 6-13 ZAP units with the incorporation of either specific IgG or exogenous complement, and increased to 23 ZAP units when both $\mathrm{IgG}$ and complement were added.

The relative capacity of representative type III GBS-serum reactants to enhance PMN adherence for protein-coated glass substrates was also directly related to their chemotaxigenic and aggregating activities. Increased adherence values were observed with incorporation of high antibody adult serum $(n=5)(\bar{x}=68 \%)$ as compared to values achieved with low antibody adult sera ( $n$ $=4)(\overline{\mathrm{x}}=46 \%)$, low antibody neonatal sera $(n=5)(\overline{\mathrm{x}}=33 \%)$ and GBS organisms alone $(\bar{x}=27 \%$ ). Anti-C5 serum (but not antialbumin) neutralized the adherence promoting capacities of these test sera.

Relationship between chemotaxigenic and opsonic activity generated in serum by type $I I I$ GBS. A previously described phagocytosis-CL assay (4) was utilized to quantitate opsonins for type III GBS (M732) in selected test sera employed in CTG assays. Opsonic CL activities generated in these test sera were compared to respective chemotaxigenic and aggregating activities (Table 3 ). The relative $C L$, chemotaxigenic, and aggregating activities among test sera were comparable. Values for each functional assay in both adult and neonatal sera were directly related to the serum concentration of specific antibody. Mean CL values noted in low antibody-containing neonatal sera was significantly $(P<0.01)$ diminished compared to adult sera containing high, low, or undetectable concentrations of specific antibody. As observed in CTG and aggregometry experiments, reconstitution of opsonic activity in hypogammaglobulinemic adult serum was also achieved with addition of purified IgG. As has been previously described (4), the majority of opsonic activity in test sera remained after MgEGTA chelation, indicating the importance of the alternative complement pathway in generation of opsonins for type III GBS (M732). These studies indicate that the opsonic and chemotaxigenic requirements for type III GBS are similar, and that abnormalities of both functions observed in neonatal sera are related to quantitative deficiencies of specific anticapsular antibody and functional abnormalities of serum complement.

Generation of chemotactic activity from purified C 5 preparations. A partially purified C5 preparation was reacted with log phase, 
type III GBS and with the supernatants of log or lag phase organisms. For these experiments, the final $\mathrm{C} 5$ concentration was adjusted to that of $25 \%(\mathrm{v} / \mathrm{v})$ serum. Supernatants of these reaction mixtures were employed in Boyden chambers in the usual manner. Only minimal chemoattractant activity $(-3$ to $+2 \mu \mathrm{m} / 80 \mathrm{~min})$ as compared to C5 incubated in the absence of GBS and essentially no aggregating activity was observed in these preparations. These findings suggest that direct (proteolytic) activation of $\mathrm{C} 5$ by an agent(s) elaborated by type III GBS does not significantly contribute to overall CTG in human serum.

\section{DISCUSSION}

The present study was designed to define chemotaxigenic requirements in serum for type Ia and type III strains of GBS and to evaluate the possibility that impaired CTG by GBS may be of pathogenic significance in neonates. Our studies demonstrate that serum complement-derived peptides (C5a and C5a des-arg) (12, 18,42 ) account for the majority of chemotactic activity derived from GBS-serum interactions, and that chemotactic factors elaborated by GBS independent of serum are quantitatively of less overall importance. These findings are in accord with observations previously reported for other bacterial pathogens $(24,48,49)$.

Our findings indicate that type specific antibody is required for maximal CTG by the GBS serotypes evaluated; low antibody concentrations in adult or neonatal serum samples significantly limited their chemotaxigenic capacity. Dose-dependent enhancement of activity by type III GBS in hypogammaglobulinemic serum was observed upon addition of an $\mathrm{IgG}$ preparation containing a high concentration of antibody to the native type III polysaccharide of GBS. Parallel findings were observed with respect to opsonic and aggregating activities when this IgG preparation was restored to hypogammaglobulinemic adult serum or low antibody-containing neonatal serum.

The requirement for serum complement in facilitating CTG by GBS was shown by the abrogation of C5a generation in heated sera and by the failure of specific IgG to restore activity when added back to heat-inactivated sera or complement deficient neonatal sera. The requirements of specific antibody and complement for maximal CTG by GBS are in accord with those reported for other pathogenic bacterial pathogens. CTG in fresh sera by washed E. coli organisms or Salmonella enteritidis endotoxin has been shown by depend upon the presence of type-specific antibody (24). Classical complement components, IgG, and an intact alternative complement pathway are also required to allow maximal CTG in sera by purified cell walls or peptidoglycan moieties of staphylococci $(10,39)$.

ACP-dependent CTG by type III GBS was demonstrated by employing MgEGTA chelation and C4 deficient GPS containing varying concentrations of specific antibody. Generation of $\mathrm{C} 5 \mathrm{a}$ in chelated sera was delayed, but that achieved after 45-min incubation intervals was only slightly diminished compared to untreated sera. Activity generated in chelated or C4D GPS was directly related to the concentration of specific antibody in the reaction mixture. Antibody facilitation of ACP activation by type III GBS has been previously described in studies of serum opsonins for this serotype (16). Our present studies indicate that type III GBS generate quantitatively similar opsonic and chemotaxigenic activity in serum via the ACP and that both functions are facilitated by specific antibody when complement function is intact.

These and other studies indicate that ACP-mediated C5a generation may represent an important host defense mechanism. ACP-derived CTG in serum or plasma has been reported for endotoxins of a variety of gram negative organisms and for encapsulated or nonencapsulated Cryptococcus neoformans (16, $28,41,49)$. Of interest is the observation that polysaccharide capsules of $C$. neoformans impair opsonophagocytosis via the ACP while allowing generation of C5a by GBS was not explored in the present study but our data do not indicate a dissociation between serum opsonic and chemotaxigenic activation by type III GBS
Direct proteolytic attack on $\mathrm{C} 5$ by bacterial proteases represents a separate mechanism whereby bacteria can generate chemotactic activity in serum (49). Proteases directly stimulating chemotactic activity have been identified for other streptococcal species and for Serratia marcescens $(45,47)$, and elaboration of proteases by GBS has been previously reported (44); however, our studies failed to demonstrate significant generation of C5a from a partially purified C5 preparation directly by GBS organisms or by filtrates of GBS suspensions.

The contribution of impaired CTG to the pathogenesis of GBS infection in human neonates or other high risk populations is unknown. Diminished CTG has been documented in inherited or acquired deficiency of $\mathrm{Clr}, \mathrm{C} 4, \mathrm{C} 2, \mathrm{C} 3, \mathrm{C} 5$ and C3bINA $(2,3)$, systemic lupus erythematosis (3), diabetes mellitus (34), hypogammaglobulinemia (13), and in nephrotic syndrome associated with low serum levels of Factor B (6). The present study demonstrates that CTG by type III GBS in sera of fullterm healthy neonates is impaired. More striking abnormalities of CTG could exist for premature neonates because IgG concentrations and maturation of complement function in neonatal sera are directly related to gestational age $(17,26)$.

\section{REFERENCES AND NOTES}

1. Adamkin, P., Stitzel, A., Urmson, J., Farnett, M. L., Post, E., and Spitzer, R.: Activity of the alternate pathway of complement in the newborn infant. $J$. Pediatr., 93: 604 (1978)

2. Alper, C. A., Abramson, N., Johnston, R. B., Jandl, J. H., and Rosen, R. S.: Increased susceptibility to infection associated with abnormalities of complement mediated functions of the third component of complement. N. Engl. J. Med., 282: 349 (1970).

3. Alper, C. A., Abramson, N., Johnston, R. B., and Rosen, R. S.: Studies in vivo and in vitro of an abnormality in the metabolism of $\mathrm{C} 3$ in a patient with increased susceptibility to infection. J. Clin. Invest., 49: 1975 (1980).

4. Anderson, D. C., Edwards, M. S., and Baker, C. J.: Luminol-enhanced chemiluminescence for evaluation of type III group B streptococcal opsonins in human sera. J. Infect. Dis., 141: 370 (1980).

5. Anderson, D. C., Hughes, B. J., and Smith, C. W.: Abnormal mobility of neonatal polymorphonuclear leukocytes. J. Clin. Invest., 68: 863 (1981).

6. Anderson, D. C., York, T. L., Rose, G., and Smith, C. W.: Assessment of serum Factor B, serum opsonins, granulocyte chemotaxis, and infection in nephrotic syndrome of children. J. Infect. Dis., 140: I (1979).

7. Baker, C. J., Edwards, M. S., and Kasper, D. L.: Role of antibody to native type III polysaccharide of group B Streptococcus in infant infection. Pediatrics, 68 : 544 (1981).

8. Baker, C. J., Edwards, M. S., Webb, B. I., and Kasper, D. L.: Antibody independent classical pathway-mediated opsonophagocytosis of type Ia, group B Streptococcus. J. Clin. Invest., 69: 394 (1982).

9. Baker, C. J., Kasper, D. L., Tager, I. B., Paredes, A., Alpert, S., McCormack, W. M., and Goroff, D.: Quantitative determination of antibody to capsular polysaccharide in infection with type III strains of group B Streptococcus. J. Clin. Invest., 59: 810 (1977).

10. Bassell, R. J., Wilkinson, P. C., McInroy, R. J., McKay, S., McCartney, A. C., and Arbuthnott, J. P.: Effects of staphylococcal products on locomotion and chemotaxis of human blood neutrophils and monocytes. J. Med. Microbiol., 8: 433 (1976).

11. Buffone, G. J.: Immunonephelometric and turbidimetric measurement of specific plasma proteins. In: N. R. Rose and H. Friedman, Ed.: Manual of Clinical Immunology. pp. 23-28 (American Society for Microbiology, Washington, D. C., 1980).

12. Chenowith, D. E. and Hugli, T. E.: Demonstration of specific C5a receptor on intact human polymorphonuclear leukocytes. Proc. Natl. Acad. Sci. USA, 75: 3943 (1978).

13. Clark, R. A.: Disorders of granulocyte chemotaxis. In: J. I. Gallin and P. G. Quie, eds.: Leukocyte Chemotaxis. pp. 329-356 (Raven Press, New York, NY 1978).

14. Craddock, P. R., Hammerschmidt, D. E., White, J. G., Dalmasso, A. P., and Jacob, H. S.: Complement (C5a)-induced granulocyte aggregation in vitro; a possible mechanism of complement-mediated leukostasis and leukopenia. J. Clin. Invest., 60: 261 (1977).

15. Edwards, M. S., Baker, C. J., and Kasper, D. L.: Opsonic specificity of human antibody for the type III polysaccharide of group B Streptococcus. J. Infect. Dis., 140: 1004 (1979).

16. Edwards, M. S., Nicholson-Weller, A., Baker, C. J., and Kasper, D. L.: The role of specific antibody in alternative complement pathway-mediated opsonophagocytosis of type III, group B Streptococcus. J. Exp. Med., 151: 1275 (1980).

17. Evans, H. E., Akpata, S. O., and Glass, L.: Serum immunoglobulin levels in premature and full-term infants. Amer. J. Clin. Pathol., 56:416 (1971)

18. Fernandez, H. N., Henson, P. M., Otani, A., and Hugli, T. E.: Chemotactic response to human $\mathrm{C} 3 \mathrm{a}$ and $\mathrm{C} 5 \mathrm{a}$ anaphylatoxins. J. Immunol., 120: 109 (1978).

19. Gallin, J. E.: Disorders of phagocyte chemotaxis. Ann. Intern. Med., 92: 520 (1980). 
20. Hammer, C. H., Wirtz, G. H., Ranfer, L., Gresham, H. D., and Tack, B. F.: Large scale isolation of functionally active components of the human complement system. J. Biol. Chem., 256: 3995 (1981).

21. Hammerschmidt, D. E., Craddock, P. R., McCullough, J., Kronenberg, R. S., Dalmasso, A. P., and Jacob, H. S.: Complement activation and pulmonary leukostasis during nylon fiber filtration leukapheresis. Blood, 51: 721 (1978).

22. Hemming, V. G., Hall, R. T., Rhodes, P. G., Shigeoka, A. O., and Hill, H. R.: Assessment of group B streptococcal opsonins in human and rabbit serum by neutrophil chemiluminescence. J. Clin. Invest., 58: 1397 (1979)

23. Keller, H. V., Hess, M. W., and Coltier, H.: The in vitro assessment of leukocyte chemotaxis. Antibiot. Chemother., 19: 112 (1974).

24. Keller, H. U. and Sorkin, E.: Studies on chemotaxis. V. On the chemotactic effect of bacteria. Int. Arch. Allergy Appl. Immunol., 31: 505 (1976).

25. Klein, R. B., Fisher, T. J., Gard, S. W., Bibertein, M., Rich, K. C., and Stiehm, R.: Mononuclear and polymorphonuclear chemotaxis in newborn infants and young children. Pediatrics, 60: 467 (1977).

26. Kohler, P. E.: Maturation of the human complement system. I. Onset of the time and site of fetal Clq, C4, C3 and C5 synthesis. J. Clin. Invest., 52: 671 (1973).

27. Kretschmer, R. R., Stewardson, P. B., Papionniate, C. K., and Gotoff, S. P.: Chemotactic and bactericidal capacities of human newborn monocytes. J. Immunol., 117: 1303 (1976).

28. Laxalt, K. A. and Kozel, T. R.: Chemotaxigenesis and activation of the alternative complement pathway by encapsulated and non-encapsulated Cryptococcus neoformans. Infect. Immun., 26:435 (1979).

29. Mancini, G., Carbonara, O., and Heremans, J.: Immunochemical quantitation of antigens by single radial immunodiffusion. Immunochemistry, 2:235 (1965).

30. Mayer, M. M.: Complement and complement fixation. In: E. A. Kabat, Ed.: Experimental Immunochemistry. pp. 133-240 (Charles C. Thomas, Springfield, IL, 1971). 2nd ed.

31. Mease, A. D., Fischer, G. W., Hunter, K. W., and Ruymann, F. B.: Decreased phytohemagglutinin-induced aggregation and $\mathrm{C} 5 \mathrm{a}$-induced chemotaxis of human newborn neutrophils. Pediatr. Res., 14: 142 (1980).

32. Miles, A. A., Miles, E. M., and Burke, J.: The value of duration of defense reactions of the skin to the primary lodgement of bacteria. Brit. J. Exp. Pathol,, 38:79 (1957).

33. Miller, M. E.: Chemotactic function in the human neonate. Humoral-cellular aspects. Pediatr. Res., 5: 487 (1971).

34. Miller, M. E. and Baker, L.: Leukocyte functions in juvenile diabetes mellitus: humoral and cellular aspects. J. Pediatr., 81 : 979 (1972).

35. O'Flaherty, J. T., Kreutzer, D. L., and Ward, P. A.: Chemotactic factor influences on the aggregation, swelling, and foreign surface adhesiveness of human leukocytes. Amer. J. Pathol., 90: 537 (1978).

36. Pahwa, S., Pahwa, R., and Grimes, E.: Cellular and humoral components of monocyte and neutrophil chemotaxis in cord blood. Pediatr. Res., 11:677 (1977).
37. Quie, P. G. and Cates, L. K.: Clinical manifestations of disorders of neutrophil chemotaxis. In: J. I. Gallin and P. G. Quie, Eds.: Leukocyte Chemotaxis. pp. 307-328 (Raven Press, New York, NY, 1974).

38. Sawyer, M. K., Burman, M. L., Kuplin, L. S., and Stiehm, E. R.: Developmental aspects of the human complement system. Biol. Neonate, 19: 148 (1971).

39. Schmeling, D. J., Peterson, P. K., Hammerschmidt, D. E., Kim, Y. K., Verhoef, J., Wilkenson, B. J., and Quie, P. G.: Chemotaxigenesis by cell surface components of Staphylococcus aureus. Infect. Immun., 26: 57 (1979).

40. Smith, C. W., Hollers, J. C., and Patrick, R. A.: Motility and adhesiveness in human neutrophils. J. Clin. Invest., 63: 221 (1979).

41. Snyderman, R., Gewurz, H., and Mergenhagen, S. E.: Interactions of the complement system with endotoxin lipopolysaccharide generation as a factor chemotactic for polymorphonuclear leukocytes. J. Exp. Med., 128: 259 (1968)

42. Snyderman, R., Phillips, J. K., and Mengenhagen, S. E.: Biological activity of complement in vivo: Role of $\mathrm{C} 5$ in the accumulation of polymorphonuclear leukocytes in inflammatory exudates. J. Exp. Med., 134: 1131 (1971).

43. Steinbuch, M., and Audran, R.: The isolation of IgG from mammalial sera with the aid of caprylic acid. Arch. Biochem. Biophys., 135:279 (1969).

44. Straus, D. C., Mattingly, S. J., Milligan, T. W., Doran, T. I., and Nelson, T. J. Protease production by clinical isolates of type III group B streptococci. J. Clin. Microbiol., 12: 421 (1980).

45. Taylor, F. B. and Ward, P. A.: Generation of chemotactic activity in rabbit serum by plasminogen-streptokinase mixtures. J. Exp. Med., 126: 149 (1967).

46. Tono-Oka, T., Nakayama, M., Uehara, H., and Matsumoto, S.: Characteristics of impaired chemotactic function in cord blood leukocytes. Pediatr. Res., 13: 148 (1979).

47. Ward, P. A., Chapitis, J., Conroy, M. C., and Lepow I. H.: Generation by bacterial proteinases of leukotactic factors from human serum and human $\mathrm{C} 3$ and C5. J. Immunol., 110: 1003 (1973).

48. Ward, P. A., Lepow, I. H., and Newman, L. J.: Bacterial factors chemotactic for polymorphonuclear leukocytes. Am. J. Pathol., 52: 725 (1968).

49. Wilkinson, P. C.: Leukocyte locomotion and chemotaxis: effects of bacteria and viruses. Rev. Infect. Dis., 2: 293 (1980).

50. Zigmond, S. H. and Hirsch, J. G.: Leukocyte locomotion and chemotaxis: New methods for evaluation and demonstration of cell-derived chemotactic factor. J. Exp. Med., 137: 387 (1973).

51. Request for reprints should be addressed to: Dr. D. C. Anderson, Texas Children's Hospital, 6621 Fannin, Houston, Texas 77030 (USA).

52. This research was supported in part by the U. S. Department of Agriculture Children's Nutrition and Research Center, Texas Children's Hospital, Houston Texas, the American Heart Association, Texas Affiliate, grants AI 13249 and AI 19031 from the National Institute of Allergy and Infectious Diseases, and Biomedical Research Support Grant 10256 to the Baylor College of Medicine. 53. Received for publication May 7, 1982.

54. Accepted for publication September 23, 1982. 